\title{
Short-term changes in particulate fluxes measured by drifting sediment traps during end summer oligotrophic regime in the NW Mediterranean Sea
}

\author{
J. C. Marty ${ }^{1,2}$, M. Goutx ${ }^{3}$, C. Guigue ${ }^{3}$, N. Leblond ${ }^{1,2}$, and P. Raimbault ${ }^{3}$ \\ ${ }^{1}$ CNRS/INSU, Laboratoire d'Océanographie de Villefranche (UMR 7093), 06230 Villefranche-sur-Mer, France \\ ${ }^{2}$ Université Pierre et Marie Curie-Paris 6, Laboratoire d'Océanographie de Villefranche, BP 8, \\ 06238 Villefranche-sur-Mer CEDEX, France \\ ${ }^{3}$ Laboratoire de Microbiologie, Géochimie et Ecologie Marines, Université de la Méditerranée; Centre d'Océanologie de \\ Marseille, CNRS (UMR 6117), Campus de Luminy, case 901, 13288 Marseille Cedex 09, France
}

Received: 24 October 2008 - Published in Biogeosciences Discuss.: 13 January 2009

Revised: 31 March 2009 - Accepted: 15 May 2009 - Published: 20 May 2009

\begin{abstract}
Short-term changes in the flux of particulate matter were determined in the central north western Mediterranean Sea (near DYFAMED site) using drifting sediment traps at $200 \mathrm{~m}$ depth in the course of the DYNAPROC 2 cruise (14 September-17 October 2004). In this period of marked water column stratification, POC fluxes varied by an order of magnitude, in the range of $0.03-0.29 \mathrm{mgC} \mathrm{m}^{-2} \mathrm{~h}^{-1}$ over the month and showed very rapid and high variations. Particulate carbon export represented less than 5\% of integrated primary production, suggesting that phytoplankton production was essentially sustained by internal recycling of organic matter and retained within the photic zone. While PON and POP fluxes paralleled one another, the elemental ratios $\mathrm{POC} / \mathrm{PON}$ and $\mathrm{POC} / \mathrm{POP}$, varied widely over short-term periods. Values of these ratios generally higher than the conventional Redfield ratio, together with the very low chlorophyll a flux recorded in the traps (mean $0.017 \mu \mathrm{g} \mathrm{m}^{-2} \mathrm{~h}^{-1}$ ), and the high phaeopigment and acyl lipid hydrolysis metabolite concentrations of the settling material, indicated that the organic matter reaching $200 \mathrm{~m}$ depth was reworked (by grazing, fecal pellets production, degradation) and that algal sinking, dominated by nano- and picoplankton, made a small contribution to the downward flux. Over time, the relative abundance of individual lipid classes in organic matter $(\mathrm{OM})$ changed from glycolipids-dominated to neutral (wax esters, triacylglycerols) and phospholipidsdominated, suggesting ecosystem maturation as well as rapid
\end{abstract}

Correspondence to: J. C. Marty (marty@obs-vlfr.fr) and continual exchanges between dissolved, suspended and sinking pools. Our most striking result was documenting the rapid change in fluxes of the various measured parameters. In the situation encountered here, with dominant regenerated production, a decrease of fluxes was noticed during windy periods (possibly through reduction of grazing). But fluxes increased as soon as calm conditions settle.

\section{Introduction}

The vertical flux of particulate biogenic matter out of the photic zone is highly variable on seasonal and annual time scales (Buesseler, 1998).Temporal pattern and its relation to hydrography and pelagic system dynamics have been documented for various oceanic and coastal regions at different latitudes (Deuser et al., 1981; Miquel et al., 1993; Steinberg et al., 2001). Seasonality is certainly the most dominant scale. Although Eppley and Peterson (1979) conceptually linked vertical fluxes to autotrophic new production, on small temporal and spatial scales, vertical fluxes may be decoupled from ambient new and regenerated production and reflect more likely pelagic food web interactions than nutrient sources for primary production (Legendre and Gosselin, 1989; Peinert et al., 1989). The export flux of particulate organic carbon can represent more than $50 \%$ of the primary production in high latitude systems but less than $10 \%$ in oligotrophic waters (Buesseler, 1998). In the Mediterranean Sea, the export ratio was even lower, reaching around $1 \%$ of the primary production (Karl et al., 2003; Moutin and Raimbault, 2002). These variations in export ratios are mostly

Published by Copernicus Publications on behalf of the European Geosciences Union. 
driven by changes in particulate fluxes rather than changes in primary production. The variations of the vertical flux of particulate biogenic matter out of the photic zone suggest variations in biogeochemical processes including, but not limited to, possible changes in community structure (Karl et al., 2003). Buesseler (1998) showed that high export events appear to be related to the composition of the phytoplankton assemblages and more specifically to the occurrence of diatom blooms and large cells in the photic zone (Boyd and Newton, 1995, 1999). Lee et al. (2008) studied the mechanistic of aggregate formation, mineral dissolution, organic carbon degradation and transport to depth, concluding that ballast is important but perhaps more as a nucleator of aggregates and as a protection against organic matter degradation rather than due to its excess density.

The effect of short-term events is poorly understood because the resolution of sediment trap sampling is rarely shorter than days or weeks (Ittekkot et al., 1996). In fact, very little data exists on short-term (hour to day) variations fluxes of particulate matter. For instances, short-term variability in the Mediterranean Sea during spring can be as high as inter seasonal fluxes variations (Goutx et al., 2002).

The multidisciplinary cruise DYNAPROC 2, a one-month long cruise undertaken in the central part of the Ligurian Sea (NW Mediterranean Sea, DYFAMED site), allowed us to study the short term changes in rates of particle export during the late summer period. Physical, chemical and biological processes were studied in the upper layer at high frequency (6-8 profiles per day) and particle were collected using drifting sediment traps deployed at $200 \mathrm{~m}$ depth during four experiments 5 days long each during the cruise. In the traps, carbon, nitrogen, phosphorus together with HPLC-measured pigments and Iatroscan-measured lipid classes were used as indicators of sources, degradation state and sedimentation processes of the particle flux.

\section{Materials and methods}

\subsection{General}

Physical, chemical and biological observations were performed during the DYNAPROC 2 cruise on the R. V. Thalassa 2 from 14 September to 18 October, 2004, in the northwestern Mediterranean Sea near DYFAMED site (main station $43^{\circ} 25 \mathrm{~N} 08^{\circ} 00 \mathrm{E}$, Fig. 1). This cruise was carried out in the course of the PECHE operation of the PROOF French program. This multidisciplinary approach was similar to that of the first DYNAPROC experiment in the post-bloom period (May 1995) (Andersen and Prieur, 2000). The campaign was based on month-long multidisciplinary observations at the same station during the end of oligotrophic stratified period. In this part of the NW Mediterranean Sea the horizontal advection is weak, as demonstrated during the first May 1995 cruise (Andersen and Prieur, 2000), and the area is isolated

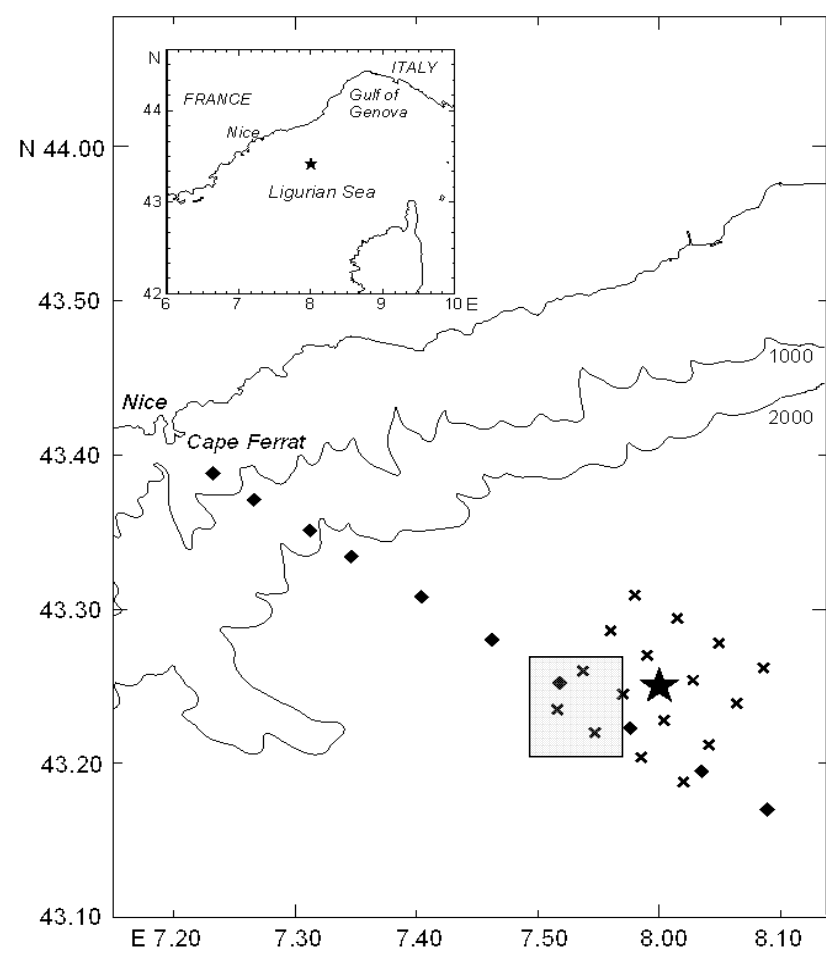

Fig. 1. Location of sampling site ( $\star$ ), stations of transect ( $\downarrow)$, grid (x), and DYFAMED zone ( $\square$ ).

from direct inputs from the coast by the presence of the Ligurian current, which flows along the coast and acts as a barrier to exchange between coastal waters and the study zone (Béthoux and Prieur, 1983). The homogeneity of the work zone and the main station was tested by precisely locating the Ligurian current during the Nice-DYFAMED transects at the beginning of each leg of the campaign, and by performing a grid of 16 stations (CTD casts) twice during the cruise (Fig. 1) to check the expected weakness of horizontal gradients.

The general strategy of the cruise was to employ a biogeochemical multidisciplinary approach during two periods of 5 days for each leg. During the four cycles, 0-500 m CTD casts were conducted at a $6 \mathrm{~h}$ minimum frequency. Drifting sediment traps (Technicap PPS $5,1 \mathrm{~m}^{2}$ opening surface) were deployed at $200 \mathrm{~m}$ depth during the four cycles (17-22 September; 24-29 September; 3-8 October, 10-15 October). The sampling interval was set at $6 \mathrm{~h}$. True replicates should have consisted to deploy at least two different traps which was obviously not possible for logistic and economic reasons. Each deployment allowed the collection of 20 samples. In case of drift out of the study zone during deployment, the sediment trap was retrieved and replaced at the original site, and this occurred once during each cycle.

Before deployment, the cups were filled with a solution of $2 \%$ buffered formalin used as preservative. After recovery of the traps, swimmers were carefully removed from cup 
content. The cup content was then split (automatic splitter) in aliquots for the various analyses using the procedure developed by Heussner et al. (1990). Aliquots were concentrated on $25 \mathrm{~mm}$ diameter Whatman $\mathrm{GF} / \mathrm{F}$ filters and stored at $-80^{\circ} \mathrm{C}$ for pigment and lipid analyses.

\subsection{Analyses}

\subsubsection{CNP}

Immediately after filtration, filters were rinsed with deionised water to eliminate residual saltwater as well as residual formalin. Then, filters were placed in $50 \mathrm{ml} \mathrm{Du}$ ran Schott bottles and stored at $-20^{\circ} \mathrm{C}$ until analysis. Particulate carbon, nitrogen and phosphorus collected on filters were determined using a wet-oxidation procedure according to Raimbault et al. (1999). First, filters were wetted with $100 \mu \mathrm{l}$ of $0.5 \mathrm{~N} \mathrm{H}_{2} \mathrm{SO}_{4}$ to remove inorganic carbon. Then, $40 \mathrm{ml}$ of deionised water and $5 \mathrm{ml}$ of oxidizing reagent ( $30 \mathrm{gl}^{-1}$ sodium tetraborate $+15 \mathrm{gl}^{-1}$ potassium persulfate) were added in the bottles. Oxidation was performed in an autoclave at 1 bar and $120^{\circ} \mathrm{C}$ during $20 \mathrm{~min}$. After cooling, inorganic forms of carbon $\left(\mathrm{CO}_{2}\right)$, nitrogen (nitrate) and phosphorus (orthophosphates) were analyzed on a Technicon II AutoAnalyzer using automatic colorimetric procedures.

\subsubsection{Pigments}

Pigments were analyzed using an Agilent Technologies HPLC system composed of a degasser (1100 model), a binary pump (1100 model), an autosampler (1100 model) with temperature control $\left(4^{\circ} \mathrm{C}\right)$ and automatic injection (Rheodyne valve), a temperature-controlled column compartment and a diode array detector (1100 model). The filters of aliquots from the sediment trap were disrupted using an ultrasonic probe in $3 \mathrm{ml}$ methanol (HPLC grade) containing an internal standard. The use of the internal standard (vitamin $\mathrm{E}$ acetate) allowed for the correction of any handling errors during extraction, since extracted pigments and standard are affected equally. All steps of analysis were realized under dim light conditions. Extracts were analyzed by reverse-phase HPLC on RPC8 column (Agilent), $150 \mathrm{~mm}$ long, $3 \mathrm{~mm}$ internal diameter, and $3.5 \mu \mathrm{m}$ granulometry (Zorbax Eclipse) following the method described by Vidussi et al. (1996). The Agilent Technologies Chemstation software was used for conducting the analysis as well as for post-analytical processing. Measurements were performed at $440 \mathrm{~nm}$ (for carotenoids), $667 \mathrm{~nm}$ (for chloropigments and degradation products) and $222 \mathrm{~nm}$ (for vitamin E acetate internal standard). Pigments were identified by comparison of on-line collected absorption spectra with those of a library of spectra established from standards and from reference cultures obtained from the Villefranche sur mer culture collection.

\subsubsection{Lipids}

Lipids were extracted from the filters (precleaned $6 \mathrm{~h}$ at $450^{\circ} \mathrm{C}$ ) following the Bligh and Dyer (1959) protocol. Lipid classes were separated on chromarods and quantified on a thin layer chromatography/flame ionization detection (TLC/FID) Iatroscan TH10 apparatus model MK6s (hydrogen flow, $160 \mathrm{ml} \mathrm{min}^{-1}$; air flow, $2000 \mathrm{ml} \mathrm{min}^{-1}$ ) coupled to a compatible PC equipped with an i-Chromstar 6.1 integration system (SCPA-Bremen, Germany). Samples $(4-8 \mu \mathrm{l}$ of a $30 \mu \mathrm{l}$ solution of the lipid extract in dichloromethane) were spotted using a $10 \mu \mathrm{l}$ Hamilton syringe onto SIII chomarods previously calibrated with standard compounds (Sigma Chemical Ltd., GC grade). Most analyses were run in triplicate except for some samples in the cycles 2 and 4 , for which the totality of the lipid extract was deposited on the chomarod. The separation scheme involved five elution steps in solvent systems of increasing polarity: hexane + diethylether + formic acid, acetone, chloroform + methanol and chloroform + methanol + ammonium hydroxide (Striby et al., 1999, modified by Goutx et al., 1990). The use of these elution systems was successful in separating neutral lipid classes (hydrocarbons, sterol esters coeluting with wax esters, ketone as internal standard, triacylglycerols, free fatty acids, alcohols, sterols and diacylglycerols), chloroplast lipids (pigments, glycolipids), monoacylglycerols and non nitrogen containing phospholipids (diphosphatidylglycerides coeluting with phosphatidylglycerides) from nitrogen containing phospholipids (phosphatidylethanolamine and phosphatidylcholine). Under these conditions, the relative standard deviation of replicate analysis $(n=3)$ of the same sample spotted on adjacent rods for Iatroscan TLC-FID analysis was 2 to $10 \%$.

\section{Results}

\subsection{Hydrological and biogeochemical context}

The DYNAPROC 2 cruise was conducted at the end of the summer stratified period from 14 September to 19 October 2004. The original objective of the cruise was to study the destratification period. Nevertheless, as indicated by the hydrological series during the cruise, the stratification remained very marked and stable during the cruise with the exception of the last days of cruise (from 12 October onward).

Two principal wind events were encountered during the cruise: one during the first leg on 25 September, at the beginning of the second trap experiment and one beginning on 10 October between the trap experiments 3 and 4 (Andersen et al., 2008). The wind speed during DYNAPROC 2 cruise is plotted on Fig. 2.

Additionally some hydrologic events have been recorded: the intrusion of a lower salinity water mass $(<38.3)$ probably issued from the coast during each leg at days 


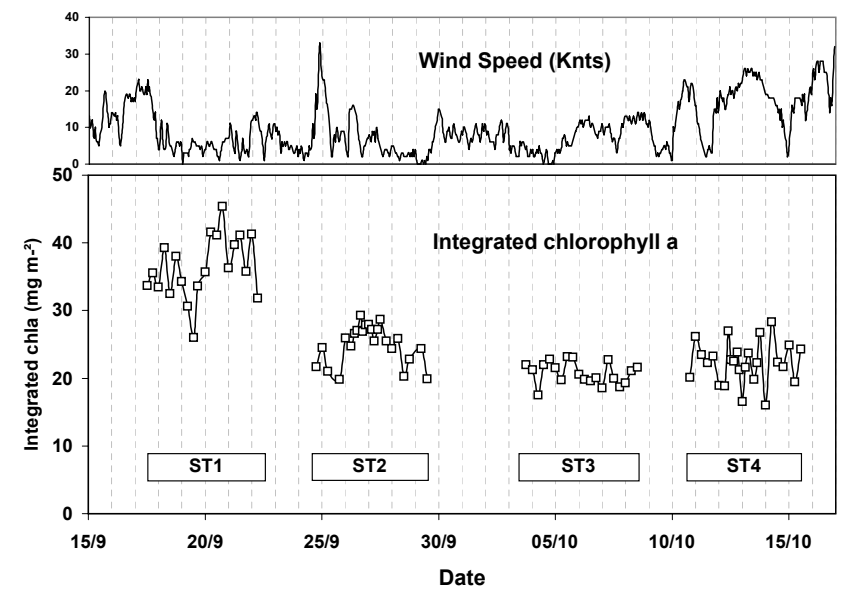

Fig. 2. Temporal changes of wind speed (knots) and integrated chlorophyll a over the $0-150 \mathrm{~m}$ water column. ST1, ST2, ST3, ST4 indicate the period of deployment of sediment traps for the 4 experiments.

23-24 September and 9-10 October (Andersen et al., 2008). The phytoplankton biomass ( $\mathrm{T}$ Chlorophyll $\mathrm{a}=$ Chlorophyll a + Divinyl Chlorophyll a) was exceptionally high at the beginning of the cruise (35-40 $\mathrm{mg} \mathrm{m}^{-2}$ ) (Marty et al., 2008) higher than generally observed at this season during the DYFAMED time-series station survey ( 10 to $30 \mathrm{mg} \mathrm{m}^{-2}$ ) with a mean of $20 \mathrm{mg} \mathrm{m}^{-2}$ (Marty et al., 2002). The biomass decreased during the cruise to $20-25 \mathrm{mg} \mathrm{m}^{-2}$ during the second leg. The integrated $\mathrm{T}$ Chlorophyll a biomass variation during the cruise is showed in Fig. 2. The biomass was dominated by pico- and nano-phytoplankton (around $87 \%$ ) with the exception of the very beginning of the cruise when diatoms were abundant (Marty et al., 2008).

\subsection{C, N, P particulate fluxes}

The temporal shifts in fluxes of organic carbon (POC), nitrogen (PON) and phosphorus (POP) collected during successive 6 hours periods appear in Fig. 3. The vertical fluxes of particulates displayed a high degree of variability over very short-time scales. POC fluxes varied by an order of magnitude, in the range $0.19-1.76 \mathrm{mgC} \mathrm{m}^{-2} 6 \mathrm{~h}^{-1}$ over the month spanned by these observations. Large fluxes events were often followed immediately by period of low flux, and produced a jagged appearance in the flux record. They were maximal at the end of cycle 1 and 2 (21 and 29 September) and during cycle 3 (5 October). They were minimal at the beginning of the cruise (17 and 18 September) and at the beginning of cycle 2 (24-27 September) and from 6 October onward.

PON and POP fluxes showed quite similar patterns and varied in the range $0.022-0.27 \mathrm{mgN} \mathrm{m}^{-2} 6 \mathrm{~h}^{-1}$ and $0.01-$ $0.027 \mathrm{mgN} \mathrm{m}^{-2} 6 \mathrm{~h}^{-1}$, respectively. Pooling all the available data, we noted a significant linear relationship between the three elements, with a slope slightly higher than the Redfield atomic ratios:

$\mathrm{POC}=7.7 \mathrm{PON}+5.5, r^{2}=0.83, n=75$

$\mathrm{POC}=169 \mathrm{POP}+21, \quad r^{2}=0.57, n=75$

$\mathrm{PON}=22 \mathrm{POP}+2, \quad r^{2}=0.68, n=75$

Nevertheless, large variations in elemental composition of sedimenting particulate matter were evident over short time scales (Fig. 4a and b). POC/PON ratio ranged between 4.3 and 16 with large variation during the cycles 2 and 4. POC/POP ratio showed similar temporal changes but with a very large range between 100 and 730 .

PON/POP ratio also displayed large variations with values ranging between 9.8 and and 136. High values $(>50)$ were essentially observed during cycle 2 . During the second part of the sampling period (cycles 3 and 4), PON/POP ratio tended to decrease from 40 to 14 while $\mathrm{POC} / \mathrm{PON}$ ratio increased from 7 to 15 . High ratios of POC/PON and POC/POP were consistent with the finding that phosphorus and nitrogen are lost more rapidly than carbon from sinking particles (Knauer et al., 1979; Lohrenz et al., 1992).

To facilitate comparisons with literature, as well as with biological assimilation of carbon measured on daily rates (Marty et al., 2008), vertical sinking fluxes of carbon, nitrogen and phosphorus converted in daily rates are given in Table 1. During the cruise, the means daily rates of sinking materials were $3.8 \pm 2.3 \mathrm{mgC} \mathrm{m}^{-2} \mathrm{~d}^{-1}$, $0.55 \pm 0.28 \mathrm{mgN} \mathrm{m}^{-2} \mathrm{~d}^{-1}$ and $0.04 \pm 0.02 \mathrm{mgP} \mathrm{m}^{-2} \mathrm{~d}^{-1}$. To provide information on the proportion of total primary production leaving the euphotic zone in the form of sinking particles, we calculated exported ratios of carbon $\left(e_{\text {ratio }}\right)$ according to Murray et al. (1989). The mean $e_{\text {ratio }}$ is $2.04 \%$ indicating that only a small part of primary production is exported through sinking particles.

No significant relationships were found between integrated daily primary production and daily POC flux, even though time-course changes in the rates appeared similar as shown in Fig. 5a. Considering $\mathrm{N}_{2}$-fixation as the main source of new nitrogen for phytoplankton and assuming a $\mathrm{C} / \mathrm{N}$ ratio of 6.6 for growth, we can calculate the amount of new carbon fixed along the cruise period. The mean primary production based on $\mathrm{N}_{2}$-fixation carbon $\left(3.1 \pm 1.1 \mathrm{mgC} \mathrm{m}^{-2} \mathrm{~d}^{-1}\right.$; Table 1$)$ was very close to the mean carbon export $\left(3.8 \pm 2.3 \mathrm{mgC} \mathrm{m}^{-2} \mathrm{~d}^{-1}\right)$. Moreover, the shorttime temporal changes showed very comparable patterns with increasing of export associated with highest primary production based on nitrogen fixation (Fig. 5b). In the same manner, the mean PON flux measured over the cruise period was $0.51 \pm 0.28 \mathrm{mgN} \mathrm{m}^{-2} \mathrm{~d}^{-1}$ and is quite similar to input of nitrogen to the photic zone due to biological $\mathrm{N}_{2}$-fixation $\left(0.54 \pm 0.19 \mathrm{mgN} \mathrm{m}^{-2} \mathrm{~d}^{-1}\right.$; Table 1$)$. 
Table 1. Vertical particulate fluxes of total mass, carbon, nitrogen and phosphorus converted in daily rates, mean primary production, new production and e ratio for the 4 collecting periods during DYNAPROC 2. The methods for tracer experiments parameters are given in Marty et al. (2008).

\begin{tabular}{|c|c|c|c|c|c|c|c|}
\hline \multirow[b]{2}{*}{ Collecting period } & \multicolumn{5}{|c|}{ Collected in sediment traps } & \multicolumn{2}{|c|}{ Tracer experiments } \\
\hline & $\begin{array}{l}\text { Total mass } \\
m g \cdot m^{-2} \cdot d^{-1}\end{array}$ & $\begin{array}{l}\text { Carbon mass } \\
\mathrm{mgC} \mathrm{m}^{-2} \mathrm{~d}^{-1}\end{array}$ & $\begin{array}{l}\text { Nitrogen mass } \\
\mathrm{mgN} \mathrm{m}^{-2} \mathrm{~d}^{-1}\end{array}$ & $\begin{array}{l}\text { Phosphorus mass } \\
\mathrm{mgPm}^{-2} \mathrm{~d}^{-1}\end{array}$ & $\begin{array}{l}\text { Primary Production } \\
\mathrm{mgC} \mathrm{m}^{-2} \mathrm{~d}^{-1}\end{array}$ & $\begin{array}{l}\text { New production } \\
\mathrm{mgC} \mathrm{m}^{-2} \mathrm{~d}^{-1}\end{array}$ & $e$ ratio \\
\hline $17 / 09$ to $22 / 09$ & $31.7 \pm 0.01$ & $5.2 \pm 1.9$ & $0.74 \pm 0.3$ & $0.07 \pm 0.02$ & $212 \pm 60$ & $3.2 \pm 1.8$ & $2.5 \%$ \\
\hline $24 / 09$ to $29 / 09$ & $17.3 \pm 0.01$ & $3.7 \pm 3.3$ & $0.47 \pm 0.28$ & $0.02 \pm 0.01$ & $197 \pm 53$ & $3.5 \pm 0.8$ & $1.9 \%$ \\
\hline $3 / 10$ to $8 / 10$ & $24.1 \pm 0.01$ & $4.2 \pm 2.1$ & $0.60 \pm 0.28$ & $0.05 \pm 0.02$ & $219 \pm 46$ & $3.2 \pm 1.0$ & $1.9 \%$ \\
\hline $10 / 10$ to $15 / 10$ & $9.5 \pm 0.01$ & $2.2 \pm 0.9$ & $0.22 \pm 0.09$ & $0.03 \pm 0.01$ & $117 \pm 16$ & $2.5 \pm 1.7$ & $1.9 \%$ \\
\hline mean value & 20.6 & $3.8 \pm 2.3$ & $0.55 \pm 0.28$ & $0.04 \pm 0.02$ & $186 \pm 60$ & $3.1 \pm 1.1$ & $2.04 \%$ \\
\hline
\end{tabular}

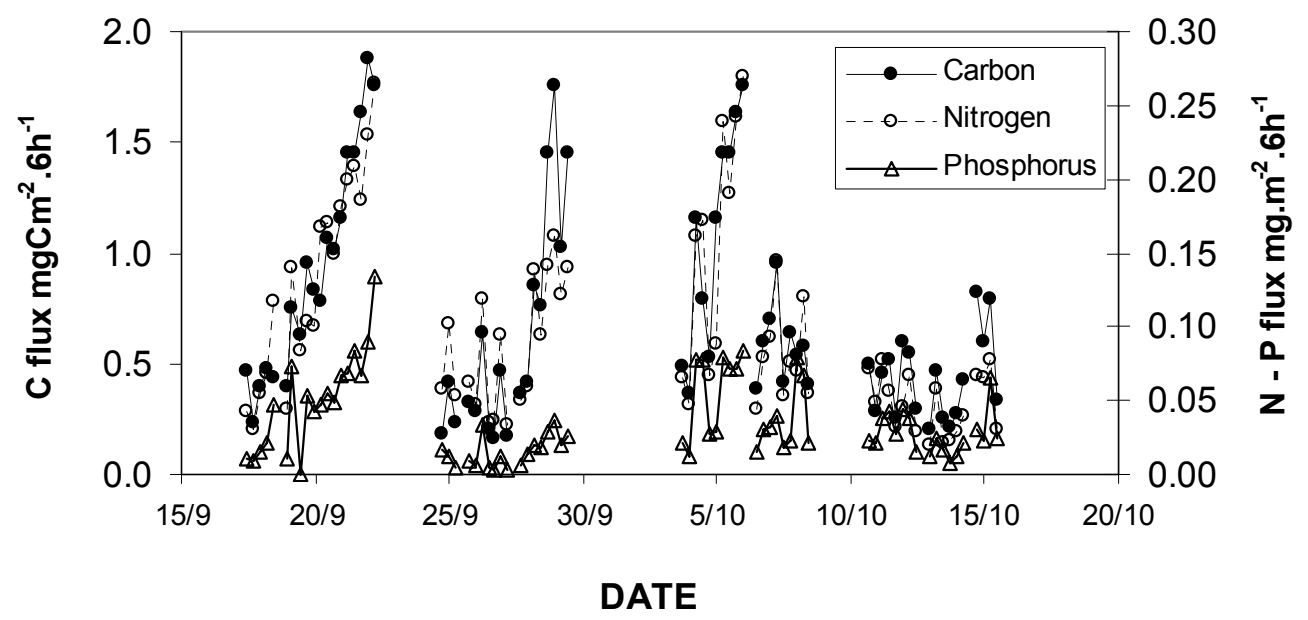

Fig. 3. Temporal changes of particulate carbon, nitrogen and phosphorus collected in sediment traps during $6 \mathrm{~h}$ of collection periods (P values have been multiplied by 5 ).

On short-time scales, export ratio $\left(e_{\text {ratio }}\right)$ was not related to primary productivity, but followed the same trend as export production (Fig. 5b) leading to significant relationship:

$e_{\text {ratio }}=0.015 \log [$ export POC $]\left(r^{2}=0.62 ; n=20\right)$

\subsection{Pigment fluxes}

Pigment fluxes recorded during the cruise are shown in Fig. 6. Chlorophyll a and phaeopigments (phaeophorbides + phaeophytins) fluxes (Fig. 6a) varied independently during the cruise. Phaeopigments dominated during cycle 1 reaching $0.5 \mu \mathrm{g} \mathrm{m}^{-2} \mathrm{~h}^{-1}$ (21-22 September) and showed a general variation comparable to that of POC. In contrast, chlorophyll a flux was maximum at the end of cycle 2 and beginning of cycle $3\left(0.06 \mu \mathrm{g} \mathrm{m}^{-2} \mathrm{~h}^{-1}\right)$. Both phaeopigments and chlorophyll a fluxes were very low for the first part of cycle 2 and for cycle 4 which corresponded to relatively windy periods. The phaeopigment/chlorophyll a ratio (Fig. 6b) was maximum during cycle 1 (mean 12) and lower during the three others cycles. Figure $6 \mathrm{c}$ shows the fluxes of major carotenoids detected in the traps during the cruise. 19'hexanoyloxyfucoxanthin (19HF) and $19^{\prime}$ butanoyloxyfucoxanthin (19BF) which are characteristics of green nanoflagellates were the major contributors to fluxes, with smaller fluxes of peridinin and fucoxanthin. The variation of fluxes along the cruise followed that of phaeophorbides, maximum at the end of cycle 1 and 2 and at mid-cycle 3 .

\subsection{Lipid fluxes}

Lipid fluxes are reported in Fig. 7. Total lipid fluxes varied in the range $8-98 \mu \mathrm{gC} \mathrm{m}^{-2} \mathrm{~h}^{-1}$. The contribution of lipids to POC flux was on average $24 \pm 11 \%$. The variation during the cruise paralleled that of POC except during cycle 1 when lipid fluxes were relatively higher during a short period (19-21 September) with a strong day/night variation. At shorter scale, the total lipid flux was minimal at the beginning of cycle 2 after the first wind event (25-27 September; 9-16 $\mu \mathrm{gC} \mathrm{m}^{-2} \mathrm{~h}^{-1}$ except 26 September, $54 \mu \mathrm{gC} \mathrm{m}^{-2} \mathrm{~h}^{-1}$ ), and also during the cycle 4 for the 

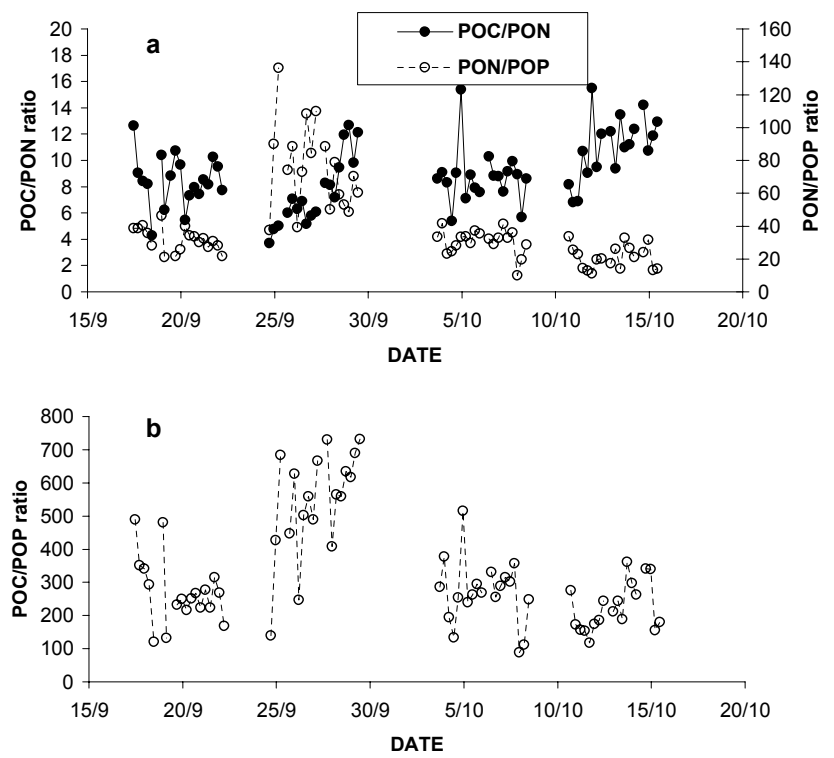

Fig. 4. Temporal changes of POC/PON and PON/OP ratios (a) and $\mathrm{POC} / \mathrm{POP}$ ratio (b) in particles collected in sediment traps during $6 \mathrm{~h}$ of collection periods
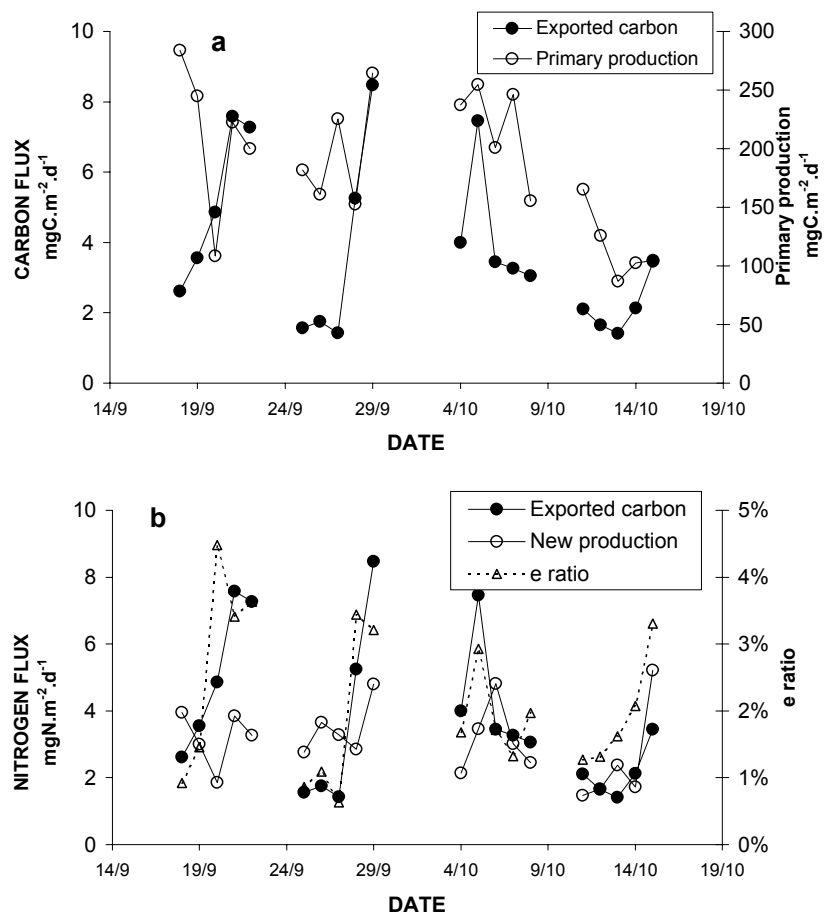

Fig. 5. Temporal changes of POC vertical flux and primary production (a) and carbon assimilation sustained by $\mathrm{N}_{2}$-fixation assuming a $\mathrm{C} / \mathrm{N}$ ratio of 6.6 and export ratio $\left(\mathrm{e}_{\text {ratio }}\right)$ estimated on daily rates (b). second wind period from 10 October to the end of cruise. Most individual lipid class fluxes showed a similar pattern. The total phospholipids fluxes (PL) increased from 2 to $10 \mu \mathrm{gC} \mathrm{m}^{-2} \mathrm{~h}^{-1}$ during cycle 1 , and were very low $\left(<2 \mu \mathrm{gC} \mathrm{m}^{-2} \mathrm{~h}^{-1}\right)$ at the beginning of cycle 2 and during cycle 4 . The highest PL flux $\left(11.7 \mu \mathrm{gC} \mathrm{m}^{-2} \mathrm{~h}^{-1}\right)$ was noticeable during cycle 3 (6 October). Similarly, sterols (ST) fluxes were characterized by contrasted values during cycle 2, ST fluxes were very low at the beginning (24-27 September, $1.1 \mu \mathrm{gC} \mathrm{m}^{-2} \mathrm{~h}^{-1}$ ) and maximum at the end of cycle 2 (29 September, $22 \mu \mathrm{gC} \mathrm{m}^{-2} \mathrm{~h}^{-1}$ ), representing a high percentage in total lipids (27-36\%). The same contrast was observed for the glycolipids (monogalactosyldiacylglycerols, MGDG) (1.4 and $12.4 \mu \mathrm{gC} \mathrm{m}^{-2} \mathrm{~h}^{-1}$, respectively) although, unlike sterols, MGDG contribution to the total lipid flux was maximal at the early beginning of cycle 1 and during cycle 3 (in the range 20-30\%). Wax esters and triacylglycerols fluxes were maximal in cycle 3 (mean $2.4 \pm 5.4$ and $3.3 \pm 3.2 \mu \mathrm{gC} \mathrm{m}^{-2} \mathrm{~h}^{-1}, n=19$, respectively). The qualitative distribution (relative abundance) of individual lipid classes in total lipids showed a drastic change in the lipid material collected in the cups throughout the cruise period (Fig. 8). During cycle 1, chloroplast lipids (the sum of the pigments and glycolipids lipid classes) along with the metabolites (the sum of free fatty acids, alcohols, diacylglycerols and monoacylglycerols) dominated over the total lipid pool whereas during cycles 2, 3 and 4, storage lipids (triacylglycerols and wax esters) largely dominated the lipid pool.

\section{Discussion}

\subsection{Primary production and export}

When compared to the measured primary and export production the mean export ratio $\left(e_{\text {ratio }}\right)$ for the cruise was of the order of $2 \%$ (Table 1), although showing rapid changes over short-time periods (Fig. 5b). These estimates agreed well with those measured at the end of the DYNAPROC 1 cruise in oligotrophic conditions (1-2\%) (Goutx et al., 2000). The overall efficiency of carbon export to depth compared to surface primary budget was low and consistent with values found in literature for other oceanic systems (2-10\%, Buessseler, 1998) and was also consistent with those found in the oligotrophic Sargasso Sea (Lohrenz et al., 1992). In the eastern Mediterranean Sea, similar values were found, with an export efficiency of 2-3\% in the Cretan Sea (Stavrakakis et al., 2000) and less than 4\% in Adriatic (Boldrin et al., 2002). Other studies conducted in different parts of the Mediterranean Sea (Danovaro et al., 1999; Moutin and Raimbault, 2002) have reported lower carbon export efficiency when comparing the eastern (3\%) to the western basins (10\%). Our values are more consistent with values found in the eastern basin, a result not surprising since oligotrophic conditions were prevalent during this experiment (Marty et al., 2008). 

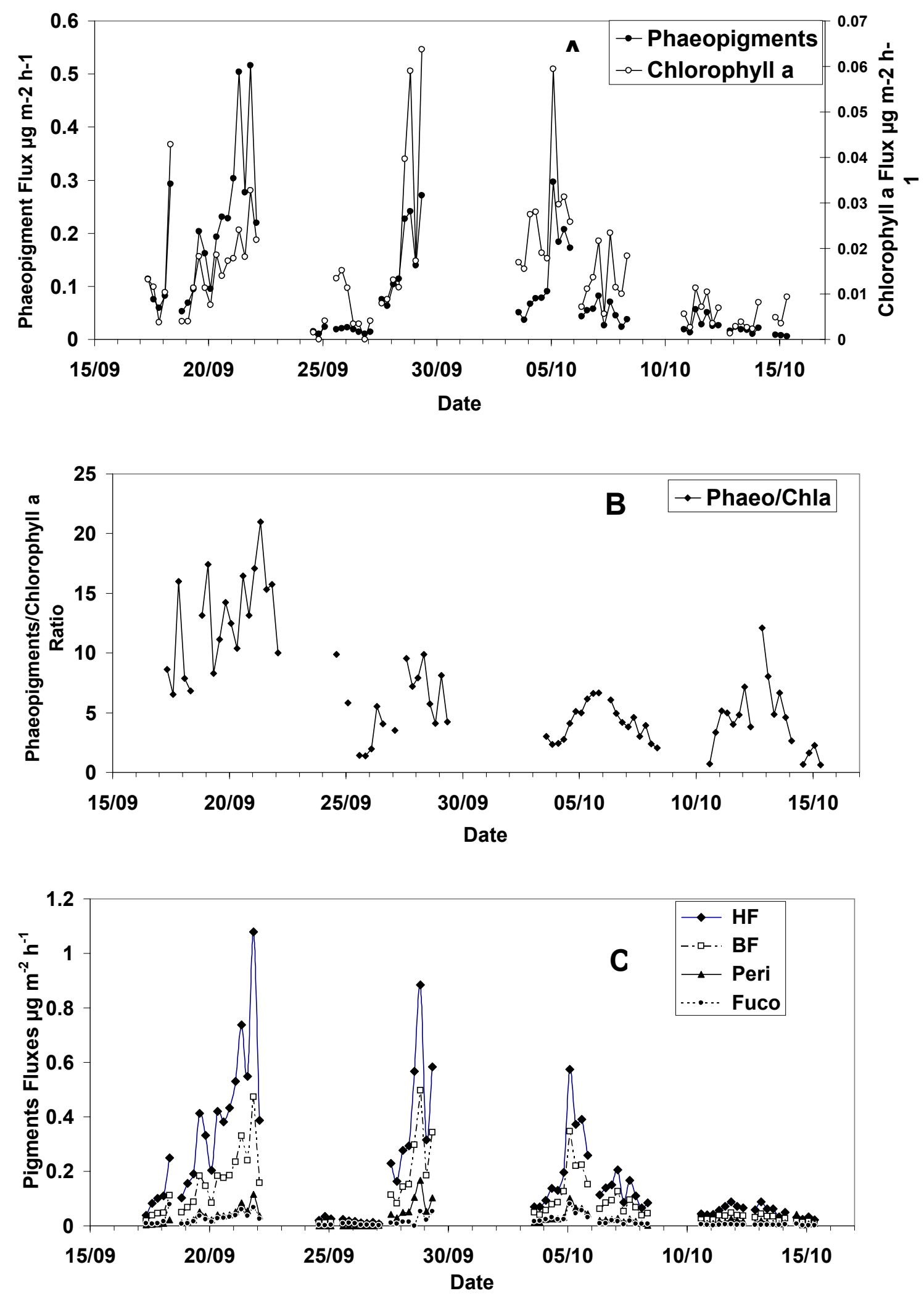

Fig. 6. Temporal changes of phaeopigments and chlorophyll- $a$ fluxes (A), phaeopigments /chlorophyll- $a$ ratio (B), and selected carotenoids fluxes (C) in sediment traps. HF: 19'Hexanoyloxyfucoxanthin; BF: 19'Butanoyloxyfucoxanthin; Peri: Peridinin; Fuco: Fucoxanthin. 

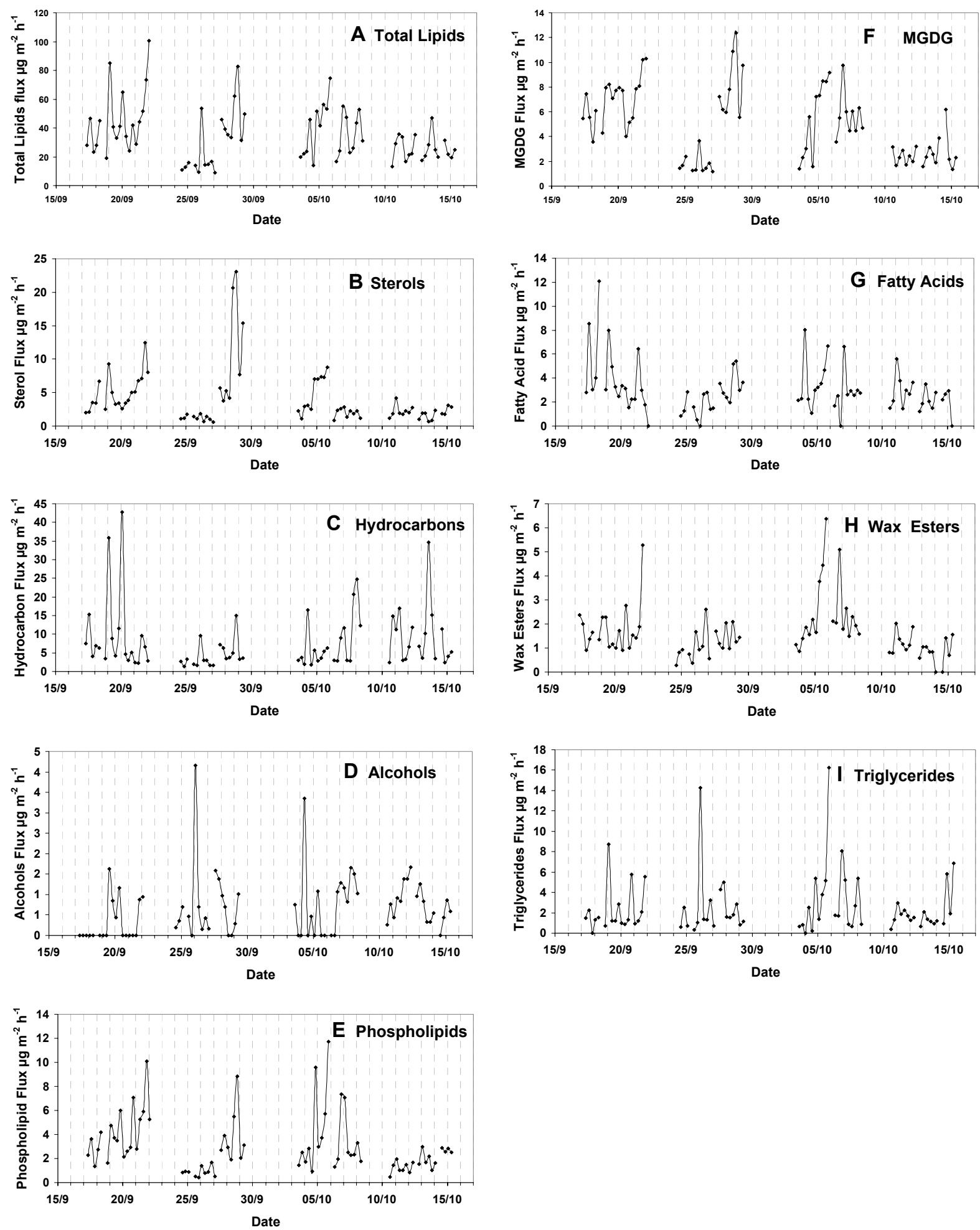

Fig. 7. Temporal changes of individual lipid classes fluxes in sediment traps. (A): Total lipids; (B): Sterols; (C): Hydrocarbons; (D): Alcohols; (E): Phospholipids; (F): Monogalactosyldiacylglycerols, MGDG; (G): Fatty Acids; (H): Wax Esters; (I): Triacylglycerols. 

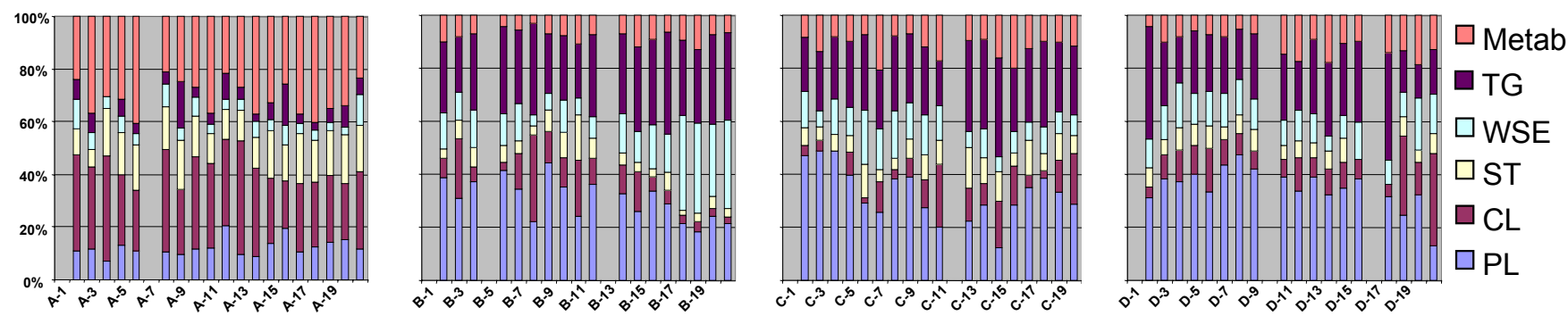

Fig. 8. Relative abundance of individual lipid classes in total lipids from DYNAPROC 2 drifting traps, late summer to autumn transition, 2004. Metab: Metabolites; TG: Triacylglycerols; WSE: Wax and sterol esters; ST: Sterols; CL: Chloroplast lipids; PL: Phospholipids.

Our rates fell in the lower part of the range of data reported by Miquel et al. (1994) for the same area during the stratified period (2-16 $\left.\mathrm{mg} \mathrm{m}^{-2} \mathrm{~d}^{-1}\right)$. Consequently, more than $95 \%$ of primary production is sustained by internal recycling of organic matter and retained in the photic zone.

The export organic nitrogen from the oceanic euphotic zone (principally as sinking particulate nitrogen) is believed to balance the input of exogenous combined inorganic nitrogen (i.e. export production balances new production, Eppley and Peterson, 1979). In the same manner, it is generally assumed that the flux of POC escaping from the photic layer is equivalent to carbon fixed during the photosynthesis process sustained by new nitrogen. In stratified oligotrophic systems, there are two significant sources of new nitrogen which can sustain carbon assimilation: the vertical diffusion of nitrate and the biological fixation of dissolved $\mathrm{N}_{2}$. During this cruise, while nutricline was always located below the thermocline leading to very low nitrate diffusion in surface waters, results of ${ }^{15} \mathrm{~N}$-tracer assays on incubated samples (Marty et al., 2008) revealed variations of integrated $\mathrm{N}_{2}$-fixation coherent with POC (Fig. 5b) and PON export. These results confirmed that 1) $\mathrm{N}_{2}$-fixation can significantly contribute to export production and 2) these two processes can rapidly vary in intensity (Karl et al., 1997; Kerhervé et al., 2001; Deutsch et al., 2007).

\subsection{Links between production regime and fluxes; com- parison with end bloom experiment (DYNAPROC 1)}

Very few sediment trap studies have employed high frequency sampling for tracking short term events. Goutx et al. (2000) described this type of time series in the first DYNAPROC cruise in May 1995, during the period of transition between spring bloom and oligotrophy. In the present study, we investigated late summer conditions. The situation studied during the cruise was characterized by a strong stratification, unusual at this period of the year where the end of stratification was generally observed (Marty et al., 2002). The stratification remained strong during the cruise at the exception of the last days, with the thermocline surrounding the nutricline inducing very low vertical diffusion of nutrients. Nevertheless the recorded phytoplankton biomass was relatively high at least at the beginning of the cruise $\left(40 \mathrm{mg} \mathrm{m}^{-3}\right.$; Fig. 2) whereas the usual integrated chlorophyll- $a$ was in the range $10-30 \mathrm{mg} \mathrm{m}^{-2}$ for the 15 years observations of DYFAMED TSS (Marty et al., 2002). The POC fluxes observed were in the range $2.2-5.2 \mathrm{mgC} \mathrm{m}^{-2} \mathrm{~d}^{-1}$ (Table 1) lower than observed during spring period $\left(34-11 \mathrm{mgC} \mathrm{m}^{-2} \mathrm{~d}^{-1}\right.$, Goutx et al., 2000).

The elemental ratios during the cruise were generally higher than the conventional Redfield ratio (Fig. 4) and indicated that the settling material was selectively degraded. Values of POC/PON ratio (mean $8.9 \pm 2.6$ ) were a little higher than those observed during the bloom period (mean $7.8 \pm 0.7$ ) (Goutx et al., 2000). POC/POP ratios show very large values (mean $326 \pm 166$, up to 730 ) suggesting that marked and rapid losses of phosphorus, and in lesser extend of nitrogen, occurred during sinking, while comparatively large amounts of carbon and nitrogen remained associated with sinking particles. No significant relationship was found between export rates and the elemental composition of the exported materials.

The chlorophyll- $a$ flux recorded in the traps during the cruise was very low (mean $0.017 \mu \mathrm{g} \mathrm{m}^{-2} \mathrm{~h}^{-1}$ ) which indicated that the organic matter reaching $200 \mathrm{~m}$ depth was reworked (by grazing, fecal pellets production, degradation) and that sedimentation of intact phytoplankton made a small contribution to the downward flux. A low contribution of algal sinking to biogenic flux in summer has been observed in other areas such as the subarctic Pacific (Thibault et al., 1999). On the other hand, the phaeopigments flux was higher $\left(0.099 \mu \mathrm{g} \mathrm{m}^{-2} \mathrm{~h}^{-1}\right)$ and indicated the more important contribution of grazing by zooplankton.

The phytoplankton system observed during the cruise (Marty et al., 2008) was characterized by the predominance of nano- and pico- phytoplankton groups which are known to be characteristic of recycled production with low export fluxes of particulate matter (Claustre, 1994; Boyd and Newton, 1999). The major carotenoids detected in the trap samples were 19-hexanoyloxyfucoxanthin (19HF) and 19-butanoyloxyfucoxanthin (19BF) which confirmed the 
contribution of nanoplankton to particulate flux. In contrast, fucoxanthin (indicator of diatoms) was present only in low concentrations, in agreement with the low concentrations of diatoms in the water column (with the exception of the very beginning of cruise) as noticed by Marty et al. (2008).

The lipid pattern reflected the contribution of both zooplankton and phytoplankton to the trap material. In addition to the presence of zoopankton biomarkers (wax esters), the flux of total lipids was significantly associated with the flux of phaeopigments $\left(r^{2}=0.42, n=74\right)$, but neither with chla nor fucoxanthin fluxes, indicating that material other than phytoplankton contributed to the flux. The contribution of pico- and nanoplankton to the lipid flux was corroborated by the significant regressions between the total lipids and 19HF $\left(r^{2}=0.49\right)$ and zeaxanthin $\left(r^{2}=0.49\right)$, and between the phytoplankton lipid biomarker, the chloroplast membrane lipids (monogalactosyldiacylglycerols, MGDG), and 19HF $\left(r^{2}=0.58\right)$ and 19BF $\left(r^{2}=0.58\right)$.

The relative abundance of individual lipid classes among total lipids reflects the background pattern of the nature of export material in relation with the production regime. For example, during the DYNAPROC 1 post-diatom bloom sampling, the relative abundance of individual lipid classes was dominated by the chloroplast lipids including the glycolipids and more or less degraded pigments, which all together indicated diatom-like material transferred to the traps through the grazing of zooplankton (Goutx et al., 2000) (Fig. 9). Interestingly, our DYNAPROC 2 study which took place during the late summer to autumn transition, documents a similar pattern of lipid class distribution in the traps (cf. Fig. 8), although during the first cycle only, when the phytoplankton biomass was still elevated in the upper productive layer. With the decline in chlorophyll concentration as the season advanced towards autumn, phospholipids, triacylglycerols and wax esters dominated the lipid material in the traps. Change in POM and DOM lipid composition from a glycolipidsdominated lipid pool, to a neutral (wax esters, triacylglycerols) and phospholipids-dominated lipid pool, has already been observed in ecosystems changing from micro- and or pico-phytoplankton to heterotrophs-dominated regimes (Smith et al., 1997; Goutx et al., 2000; Ghiglione et al., 2007; Bourguet et al., 2008). During DYNAPROC 2, a similar shift occurred in the suspended particles and dissolved matter (Goutx et al., 2009). Neutral lipids (WE+TG) significantly increased from $4.9 \% \pm 4.4$ to $18.4 \% \pm 14.3$ (test students $t=4.43, p<0.001, n=54)$ and from $2.8 \pm 3.8$ to $6.6 \pm 10.3$ (test students $t=2.01, p<0.001, n=83$ ) in suspended and dissolved lipids, respectively, between the beginning (17-22 September, cycle 1) and the end of the cruise (3-8 October, cycle 3) (data available at http://www.obs-vlfr.fr/proof/ftpv/ peche/dynaproc2/data/244_goutx/). Clearly, the changes that we observed in the surface lipid properties were reflected in the trap material. This probably indicated that rapid and continual exchanges occurred between dissolved, suspended and sinking pools during this transition period. Differences

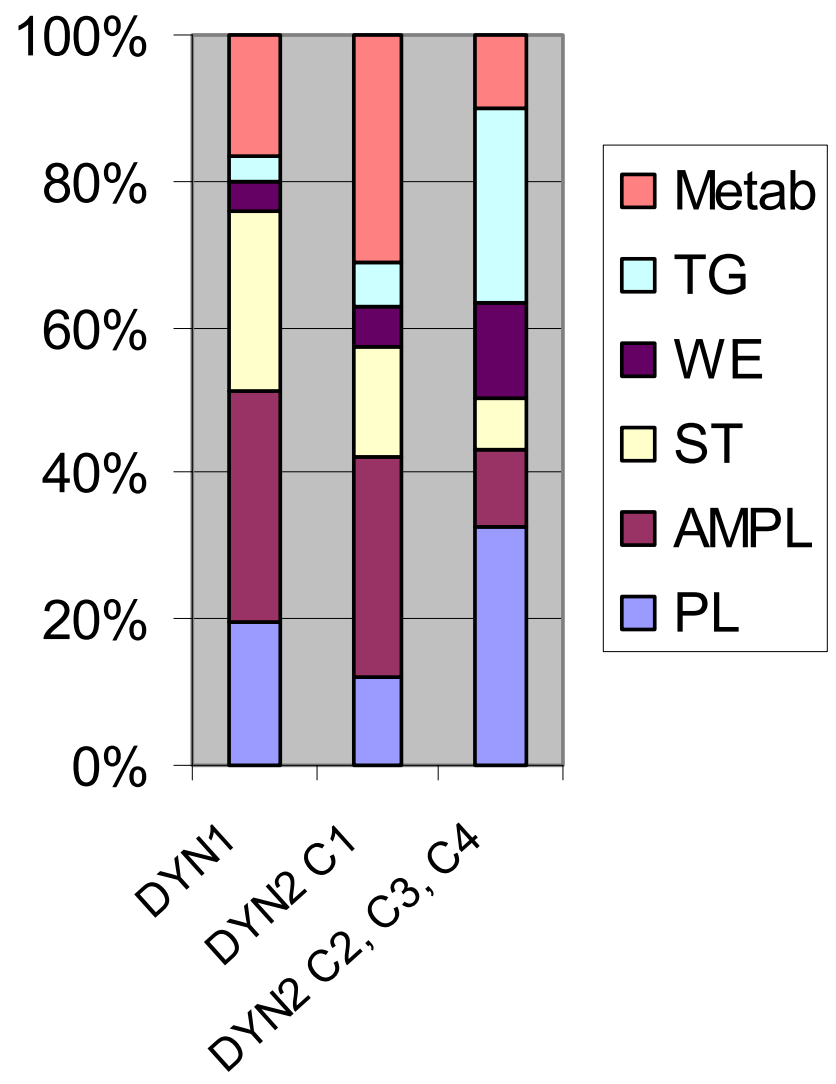

Fig. 9. Mean relative abundance of individual lipid classes in trap samples showing the dominance of chloroplast lipids ( $>20 \%)$ (AMPL) during DYNAPROC 1 and DYNAPROC 2 cycle 1 , and the dominance of phospholipids (PL), wax esters (WE) and triacylglycerols (TG) during the DYNAPROC 2 cycle 2, 3 and 4. Other individual lipid classes are metabolites (Metab) and sterols (ST).

in carbon allocation during periods of lower productivity would result in transient increases in the availability of essential, energy-rich lipids to higher trophic levels and/or to mesopelagic layer carbon limited community.

\subsection{Short-term variations (wind events, changing water masses, day/night)}

The most striking result of our study is a documentation of the rapid change in fluxes of the various measured parameters. For example, the shift in POC flux (Fig. 3) was characterized by an increase during cycle 1 , but by low values at the beginning of cycle 2 and increase again from 28 September onward. During leg 2 there was also an increase in POC flux at the beginning of cycle 3 and an abrupt decrease on 6 October and lower values for the rest of cycle 3 and for cycle 4 . The increases in fluxes appeared to be related to calm weather periods and lower fluxes were recorded during windy periods (see Fig. 2 and Andersen et al., 2008). This is the opposite of what was observed during post-bloom 
sampling (Goutx et al., 2000) where a wind event increased the flux of exported algal material.

In our study POC as well as other biogeochemical parameters fluxes increased during quiet (i.e., low wind) periods. Since primary production was relatively constant during the cruise (Table 1) and phytoplankton biomass distribution between groups was also relatively constant, the increase of flux could be linked to a more active grazing. Indeed, zooplankton exhibited several rapid increase of biomass during leg 1 and 2 (a factor of 4 in $24 \mathrm{~h}$ ) (Raybaud et al., 2008). The presence of low-salinity water masses during some periods during cycle 2 and cycle 3 , unfortunately in coincidence with wind events, was probably of less influence since the proportion of the various phytoplankton groups was only slightly affected. Although the zooplankton distribution could be different in other water masses, the main constraint in this case was probably the wind effect.

We showed that the reaction of carbon flux to wind in periods dominated by regenerated production (small species: nano-pico-phytoplankton, new production sustained by $\mathrm{N}_{2}$ fixation) was different from periods dominated by new production (large species diatoms and/or dinoflagellates). In the case of dominant new production (DYNAPROC 1), sedimentation was principally linked to algal transfer and the effect of wind events was to activate transfer through direct sedimentation. In the case of our study with dominant regenerated production, the effect of wind events was a decrease of fluxes (probably through reduction of grazing). But fluxes increased as soon as calm conditions settled. Accordingly, mesopelagic dissolved lipid signatures that we attributed to the dissolution of settling POM from zooplankton origin, only occurred during the largest period of low wind (Goutx et al., 2009).

Short term fluctuations were obvious in flux data for all the measured parameters. These variations could reach a factor of 2 in $6 \mathrm{~h}$. These abrupt variations in fluxes were partly the result of physical processes (see above) but also of biological processes. The short term periodicity of fluxes was often on the order of 12 to $24 \mathrm{~h}$. POC fluxes were generally higher during night period than during day with only rare exceptions (20 September for example). This diel periodicity of POC fluxes could be the result of the diel fluctuation in zooplankton grazing rate as evidenced by Welschmeyer et al. (1984) or Dagg et al. (1989) even if phaeopigment fluxes do not follow the same rhythm. A possible explanation of this discrepancy between organic carbon and phaeopigments may be the fact that phaeopigments are produced by micro and meso zooplankton with different sinking rates and could also be modified by photooxidation due to there long residence time in surface waters in stratified conditions, leading to colourless products (Cuny et al., 2002) which are included in the organic carbon measurement but not in phaeopigments. There was a significant increase of the biomass of total zooplankton in the 0-200 $\mathrm{m}$ surface layer at night during the experiment (Raybaud et al., 2009). Small and large copepods that dominated the zooplankton community likely released faecal pellets at night with consequence on the periodicity of the export flux. Once again, the contrast appeared between a situation where fluxes were dominated by the sedimentation of algal biomass and the situation observed here where the principal contributions to fluxes were the copepods faecal pellets.

\section{Conclusions}

The short term sedimentation characterized during DYNAPROC 2 was highly variable and linked to the nature of the phytoplankton community and physical constraints. The stratification was strong along the cruise, and the phytoplankton assemblages were dominated by small species (nano-pico phytoplankton).

As expected in these conditions of highly stratified waters, the exported fluxes were low and the exported material degraded. The flux was probably more dominated by products issued from grazing (e.g. faecal pellets of copepods) than by a direct contribution from decaying algal biomass. Up to $95 \%$ of primary production is sustained by internal recycling of organic matter and retained in the photic zone, and $\mathrm{N}_{2}$-fixation can significantly contribute to export production.

Measured fluxes were very variable at the scale of day. In general the day night periodicity of organic fluxes was apparent but of weak amplitude and linked to grazing by mesozooplankton. In this oligotrophic system, the influence of wind intensity could be the main constraint over fluxes with low fluxes during windy periods through reduction of grazing, and higher fluxes during calm periods.

Acknowledgements. This study was part of the PECHE project; financial support was provided by the I.N.S.U.-C.N.R.S. through the PROOF program (JGOFS-France). We thank the chief scientist, V. Andersen, for organising the DYNAPROC 2 cruise program, and the crew of the R/V Thalassa for ship operations. We thank $\mathrm{J}$. Dolan for English corrections. This paper is dedicated to our friend and colleague Valérie Andersen who prematurely passed away in March 2007.

Edited by: S. Pantoja

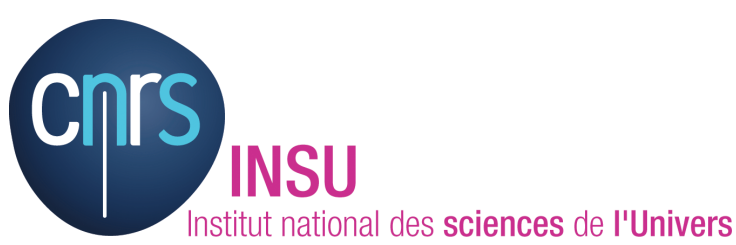

The publication of this article is financed by CNRS-INSU. 


\section{References}

Andersen, V. and Prieur, L.: One-month study in the open NW Mediterranean Sea (DYNAPROC experiment, May 1995): overview of the hydrobiogeochemical structures and effect of wind events, Deep Sea Res. Pt. I, 47, 397-422, 2000.

Andersen, V., Goutx, M., Prieur, L., and Dolan, R.: Short-scale temporal variability of physical, biological and biogeochemical processes in the NW Mediterranean Sea: an introduction, Biogeosciences Discuss., 6, 453-461, 2009,

http://www.biogeosciences-discuss.net/6/453/2009/.

Béthoux, J. P. and Prieur, L.: Hydrologie et circulation en Méditerranée Nord-Occidentale, Pétr. Tech., 299, 25-34, 1983.

Bligh, E. G. and Dyer, W. J.: A rapid method of total lipid extraction and purification, Can. J. Biochem. Physiol., 37, 911-917, 1959.

Boldrin, A., Miserocchi, S., Rabitti, S., Turchetto, M. M. Balboni, V., and Socal, G.: Particulate matter in the southern Adriatic and Ionian Sea: characterization and downward fluxes, J. Marine Syst., 33, 389-410, 2002

Bourguet N., Goutx, M., Ghiglione, J. F., Pujo-Pay, M., Mével, G., Momzikoff, A., Mousseau, L., Guigue, C., Garcia, N., Raimbault, P., Pete, R., Oriol, L., and Lefèvre, D.: Lipid biomarkers and bacterial lipase activities as indicators of organic matter and bacterial dynamics in contrasted regimes at the Dyfamed site, NW Mediterranean, Deep-Sea Res. Pt. II, doi:10.1016/j.dsr2.2008.11.034, in press, 2008.

Boyd, P. and Newton, P.: Evidence of the potential influence of planktonic community structure on the interannual variability of particulate carbon flux, Deep-Sea Res. Pt. I, 42, 619-639, 1995.

Boyd, P. W. and Newton, P. P.: Does planktonic community structure determine downward particulate organic carbon flux in different oceanic provinces?, Deep-Sea Res. Pt. I, 46, 63-91, 1999.

Buesseler, K.O.: The decoupling and production and particle export in the surface ocean, Global Biogeochem. Cy., 12, 297-310, 1998.

Claustre, H.: The trophic status of various oceanic provinces as revealed by phytoplankton pigment signatures, Limnol. Oceanogr., 39, 1207-1211, 1994.

Cuny, P., Marty, J. C., Chiaverini, J., Vescovali, I., Raphel, D., and Rontani, J. F.: One year seasonal survey of the chlorophyll photodegradation process in the northwestern Mediterranean Sea, Deep Sea Res. Pt. II, 49, 1987-2005, 2002.

Dagg, M. J., Frost, B. W., and Walser Jr., W. E.: Copepod diel migration, feeding, and the vertical flux of pheopigments, Limnol. Oceanogr., 34, 1062-1071, 1989.

Danovaro, R., Dinat, A., Duineveld, G., and Tselepides, A.: Benthic response to particles fluxes in different trophic environments: a comparison between the Gulf of Lions - Catalan sea (western Mediterranean) and the Cretan sea (eastern Mediterranean), Prog. Oceanogr., 44, 287-312, 1999.

Deuser, W. G., Ross, E. H., and Anderson, R. F.: Seasonality in the supply of sediment to the deep Sargasso Sea, and implications for rapid transfer of matter to the deep ocean, Deep-Sea Res., 28, 495-505, 1981

Deutsch, C., Sarmiento, J. L, Sigman, D. M., Gruber, N., and Dunne J. P.: Spatial coupling of nitrogen inputs and losses in the ocean, Nature, 445(7124), 163-167, 2007.

Eppley, R. W. and Peterson, B. J.: Particulate organic matter flux and planktonic new production in the deep ocean, Nature, 282, 677-680, 1979.
Ghiglione, J. F., Mevel, G., Pujo-Pay, M., Mousseau, L., Lebaron, P., and Goutx, M.: Diel and seasonal variations in abundance, activity, and community Structure of particle-attached and freeliving bacteria in NW Mediterranean Sea, Microb. Ecol., 54, 217-231, 2007.

Goutx, M., Gerin, C., and Bertrand, J. C.: An application of Iatroscan thin-layer chromatography with flame ionozation detection. Lipid classes of microorganisms as biomarkers in the marine environment, Org. Geochem., 16, 1231-1237, 1990.

Goutx, M., Momzikoff, A., Striby, L., Andersen, V., Marty, J. C., and Vescovali, I.: High-frequency fluxes of labile compounds in the central Ligurian Sea, Deep-Sea Res. Pt. I, 47, 533-556, 2000.

Goutx, M., Guigue, C., Aritio, D., Ghiglione, J. F., and Andersen, V.: Short term variability of dissolved lipid classes during summer to autumn transition in the Ligurian Sea (NW Mediterranean), Biogeosciences Discuss., 6, 27-69, 2009, http://www.biogeosciences-discuss.net/6/27/2009/.

Heussner, S., Ratti, C., and Carbonne, J.: The PPS3 time-series sediment trap sample processing techniques used during the ECOMARGE experiment, Continental Shelf Res., 10(9-11), 943958, 1990.

Ittekkot, V., Schafer, P., Honjo, S., and Depetris, P. J. (eds): Particle Flux in the ocean, Scope 57, Wiley, New York, USA, 357-367, 1996.

Karl, D. M., Bates, N., Emerson, S., Harrisson, P. J., Jeandel, C., Liu, K. K., Marty, J. C., Michaels, A. F., Miquel, J. C., Neuer, S., Nojiri, Y., and Wong, C. S.: Temporal studies of biogeochemical processes determined from ocean time-series observations during the JGOFS era, in : Ocean Biogeochemistry: The role of the ocean carbon cycle in global change, ed: M. J.R. Fasham, International Geosphere-Biosphere Programme Book Series, Springer-Verlag, 239-267, 2003.

Karl, D. M., Letelier, R., Tupas, L., Dore J., and Christian, J. D. H.: The role of nitrogen fixation in biochemical cycling in the subtropical North Pacific Ocean, Nature, 386, 533-538, 1997.

Kerhervé, P., Minagawa, M., Heussner, S., and Monaco, M.: Stable isotopes $\left({ }^{13} \mathrm{C} /{ }^{12} \mathrm{C}\right.$ and $\left.{ }^{15} \mathrm{~N} /{ }^{14} \mathrm{~N}\right)$ in settling organic matter of the northwertern Mediterraean Sea: biogeochemical implications, Oceanol. Acta, 24, S77-S85, 2001.

Knauer, G. A., Martin, J. H., and Bruland, K. W.: Fluxes of particulate carbon, nitrogen, and phosphorus in the upper water column of the northwestern Pacific, Deep-Sea Res., 37, 1121-1134, 1979.

Lee, C., Armstrong, R. A., Cochran, J. K., Engel, A., Fowler S., Goutx, M., Masqué P., Miquel J. C., Peterson, M., Tamburini, Ch. and Wakeham, S. : MedFlux: Investigations of Particle Flux in the Twilight Zone, Deep Sea Res. Pt. II, in press, doi:10.1016/j.dsr2.2008.11.029, 2008.

Legendre, L. and Gosselin, M.: New production and export of organic matter to the deep ocean : consequences of some recent discoveries, Limnol. Oceanogr., 34, 1374-1380, 1989.

Lohrenz, S. E., Knauer, G. A., Asper, V. L., Tuel, M., Michaels, A. F., and Knap, A. H.: Seasonal variability in primary production and particle flux in the northwestern Sargasso Sea: US JGOFS Bermuda Atlantic Time-series Study, Deep-Sea Res., 39, 1373 1391, 1992.

Marty, J. C., Chiaverini, J., Pizay, M. D., and Avril, B.: Seasonal and interannual dynamics of nutrients and phytoplankton pigments in the western Mediterranean Sea at the DYFAMED time- 
series station (1991-1999), Deep-Sea Res. Pt. II, 49, 1965-1985, 2002.

Marty, J. C., Garcia, N., and Raimbault, P.: Phytoplankton dynamics and primary production under late summer conditions in the NW Mediterranean Sea, Deep Sea Res. Pt. I, 55, 1131-1149, 2008.

Miquel, J. C., Fowler, S. W., La Rosa, J., and Buat-Menard, P.: Dynamics of the downward flux of particles and carbon in the open northwestern Mediterranean Sea, Deep-Sea Res. Pt. I, 41, 243-261, 1994.

Moutin, T. and Raimbault, P.: Primary production, carbon export and nutrients availability in western and eastern Mediterranean Sea in early summer 1996 (MINOS cruise), J. Mar. Res., 33-34, 273-288, 2002.

Murray, J. W., Downs, J., Strom, S., Wei, C. L., and Jannasch, H.: Nutrient assimilation, export production, and ${ }^{234} \mathrm{Th}$ scavenging in the eastern equatorial Pacific, Deep-Sea Res., 36, 1471-1489, 1989.

Peinert, R., Von Bodungen, B., and Smetacek, V.: Food web structure and loss rates, in: Productivity of the Oceans: Present and Past, edited by: Berger, W., Smetacek, V., Wefer, G., Wiley, New York, USA, 34-48, 1989.

Raimbault P., F., Diaz, and Boudjellal, B.: Simultaneous determination of particulate forms of carbon, nitrogen and phosphorus collected on filters using a semi-automatic wet-oxidation procedure, Mar. Ecol. Progr. Ser., 180, 289-295, 1999.

Raybaud, V., Nival, P., Mousseau, L., Gubanova, A., Altukhov, D., Khvorov, S., Ibanez, F., and Andersen, V.: Short term changes in zooplankton community during the summer-autumn transition in the open NW Mediterranean Sea: species composition, abundance and diversity, Biogeosciences, 5, 1765-1782, 2008, http://www.biogeosciences.net/5/1765/2008/.
Smith, R. E. H., Gosselin, M., Kattner, G., Legendre, L., and Pesant, S.: Biosynthesis of macromolecular and lipid classes by phytoplankton in the Northeast Water Polynya, Mar. Ecol. Prog. Ser., 147, 231-242, 1997.

Stavrakakis, S., Chromis, G., Tselepides, A., Heussner, S., Monaco, A., and Abassi, M.: Downward fluxes of settling particles in the deep Cretan Sea (NE Mediterranean), Progr. Oceanogr., 46, 217 $240,2000$.

Steinberg, D. K., Carlson, C. A., Bates, N. R., Johnson, R. J., Michaels, A. F., and Knap, A. H.: Overview of the US JGOFS Bermuda Atlantic time-series study (BATS): a decade-scale look at ocean biology and biogeochemistry, Deep-Sea Res. Pt. II, 48, 1405-1447, 2001.

Striby, L., Lafont, R., and Goutx, M.: Improvement in the Iatroscan thin-layer chromatography-flame ionisation detection analysis of marine lipids. Separation and quantification of mono- and diacylglycerols in standards and natural samples, J. Chromatogr. A, 849, 371-380, 1999.

Thibault, D., Roy, S., Wong, C. S., and Bishop, J. K.: The downward flux of biogenic material in the NE subarctic Pacific: importance of algal sinking and mesozooplankton herbivory, Deep-Sea Res. Pt. II, 46, 2669-2697, 1999.

Vidussi, F., Claustre, H., Bustillos-Guzmann, J., Cailliau, C., and Marty, J. C.: Determination of chlorophylls and carotenoids of marine phytoplankton: separation of chlorophyll a from divinylchlorophyll- $a$ and zeaxanthin from lutein, J. Plankton Res., 18, 2377-2382, 1996.

Welschmeyer, N. A., Copping, A. E., Vernet, M., and Lorenzen, C. J.: Diel fluctuation in zooplankton grazing rate as determined from the downward vertical flux of pheopigments, Mar. Biol., 83, 263-270, 1984. 